\title{
TELLING THE CHRISTIAN STORY \\ - BY KARL RAHNER AND ME
}

\author{
Augustine Shutte \\ Department of Philosophy \\ University of Cape Town
}

\begin{abstract}
The intelligibility of the Christian story depends upon it being told in words that do not presuppose faith; good theology depends on good philosophy. The foundation of Rahner's philosophy is his insight into the transcendent character of human nature, and thus also of the power that alone can bring about our existence or fulfilment. The incommensurability of creator and creature is experienced by us most fully in interpersonal relationships of love. Consequently all human history must be seen as the history of God's self-communication to us, as 'salvation history'. For Christians this self-communication of God is fully achieved, and so unsurpassable, in the person and life of Jesus. The result is the possibility of a true and universal community of humanity in a death-transcending life with him. The Church is the sign of Jesus' - and so God's - continuing 'real presence' with us. It is also an instrument for realising this unity and union, together with all other religious and spiritual traditions to a greater or lesser degree.
\end{abstract}

Key Words: Transcendence, Historicity, Intersubjectivity, Incommensurability, God's self-communication, Jesus the final Prophet, the Church as Sacrament, Real presence, Death-transcending life

This is the story of my theological relationship with Karl Rahner. His influence on me has been such that often the reader will not be able to tell whether it is I speaking or he. However I do not think this an entirely bad thing. I do not claim to be as great a theologian as Rahner but I have no doubt that I am a better writer. Rahner is one of the most horrifically ponderous and prolix writers that ever came from that supremely ponderous and prolix tradition that includes Hegel, Husserl and Heidegger. Even Hugo, Karl's brother, admitted that he could only understand what Karl was saying when he read him in English!

There is another reason why Karl Rahner is so difficult to read. In all his writings he is walking a tightrope stretched across the rubbish tip where lie the remains of writings forbidden by Vatican officialdom. Rahner has had to bend over backwards to keep his balance between communicating the Christian faith to a scientific and secular culture, and negotiating the minefield the history of the Church has left for the theological explorer to cross.

In most of what follows I will be expounding Rahner's idea in my words. The reader will have to take on trust that I am thoroughly grounded in both Rahner's philosophical and theological works. Not that I would claim to have read all several hundred of them. But I have studied the most important ones exhaustively: Spirit in the World, Hearers of the Word, Hominisation, The Christian of the Future, The Church and Sacraments, The Theology of Death, The Love of Jesus and the Love of Neighbour, The Practice of Faith, The Trinity and countless articles in the twenty-three volumes of his Theological Investigations, not to speak of all his contributions to dictionaries and encyclopaedias such as Sacramentum Mundi and Mysterium Salutis. 
If I intended to try and reference everything I say, not only would I never finish this article; I would never have begun it.

I first discovered the work of Karl Rahner in the late sixties when I was a member of the Dominican community in Stellenbosch. The Dominican Order was founded by St Dominic in the thirteenth century, and Thomas Aquinas - by far the most celebrated philosopher and theologian in the Catholic church - was one of its early members. So as a Dominican student I had intimate contact with his thought. And so did the Jesuit Rahner. But in addition to a common philosophical background we also had something more important in common: A desire to make sense of Christian faith in our contemporary secular culture and to formulate its basic doctrines in terms that were compatible with our contemporary worldview.

No-one in the Catholic church has done more to achieve this than Karl Rahner. At that time the Second Vatican Council was in session and Rahner was the leading theologian engaged in what Pope John had named aggiornamento - the bringing up to date of Catholic life and thought. No-one was better fitted for this task. Not only was Rahner prodigiously learned and so intimately familiar with the theological tradition (he was the then editor of Denziger, the classical compendium of authoritative Christian doctrinal texts). He was also a philosopher of the first rank, steeped in the classical tradition of European philosophy, and author of original work of his own that brought Thomist philosophy into contact with existentialism and phenomenology.

What struck me most at that time about Rahner, and filled me with admiration and the desire to emulate him, was the way he combined philosophical rigour with an absolute commitment to Christianity. He gave reasons for everything he said, never arguing from authority but from experiences that anyone could refer to in order to corroborate his arguments. And yet he simply took the tradition of faith (including its traditional formulations) as an authoritative given that needed to be explained. His articles and books were thus a continuing dialogue between the traditional language of scripture and church doctrine and the language of his own contemporary philosophy. They were both works of 'translation' and 'inculturation'.

I had come to faith in God through philosophy in the classes of Professor Martin Versfeld at UCT in the late fifties. I was an Anglican at that time and proceeded to study theology at Oxford with a view to ordination in the Anglican church. While in England I became a Catholic. One of the things that I missed in the Anglican church was a lack of a philosophical dimension in its theology. But in Stellenbosch we were encouraged to develop a philosophy of our own. Rahner was an ideal partner in this endeavour. I plunged myself enthusiastically into the vast sea of this writings. On the one side there were specifically philosophical works such as Spirit in the World, Hearers of the Word and Hominisation. On the other were the twenty-odd volumes of his Theological Investigations. But in the theology of Karl Rahner philosophical reflection and Christian faith are inseparably united.

As far as the philosophy is concerned Rahner has translated the philosophy of Aquinas into a modern idiom. Medieval philosophy was metaphysical in Aristotle's sense, namely the identification of the most fundamental concepts one has to use in thinking of anything at all. Physics, for Aquinas and Aristotle, was the application of these concepts - such notions as existence and essence, act and potency, form and matter - to the things of nature. Psychology was their application to living things, including us. Philosophy was thus, in this sense, cosmological. Everything was included. In the modern period, with the development of the natural sciences, this complete and unified system was abandoned - forever. The 
natural sciences would never be complete but continue to grow - forever. And philosophy now was able to focus on its proper object (the only thing left over because beyond the reach of science), namely human subjects who invent the sciences' methods and judge their results. The modern period saw philosophy's discovery of subjectivity, culminating in Kant's Copernican Revolution, the so-called 'transcendental turn'. From now on, starting with Hegel, and continuing with phenomenology and existentialism and linguistic philosophy, philosophy would concern itself with the exploration of human interiority. Philosophy was no longer cosmological but a kind of anthropology.

Rahner's philosophy represents a culmination of this process. One can recognize all these developments beneath the finished product. And his philosophy provides him with a medium for his theology. In what follows I will be attempting to give, in summary form, the theological vision I have acquired from, or at least share with, Karl Rahner.

1. Human beings have a dimension that transcends anything the sciences can know since it is what produces and judges the sciences. It is what makes us self-aware, self-determining subjects of thought and action, and is the source not only of science, but of morality, art, religion and, in general, culture. It is this transcendent subjectivity that makes us persons in the technical sense, spiritual as well as material beings. To say that we are spiritual is to draw attention to the peculiar internal relation human beings have to themselves (selfawareness and self-determination) that is not merely some part of us related to another part, but of ourselves as a whole in relation to the whole of ourselves. This is contrasted with our materiality which refers to the equally constitutive relationship in which we stand to all that is other than ourselves, the whole universe in fact, personal and impersonal. As spiritual beings we transcend the whole of the impersonal universe in the sense that it does not explain our existence and cannot fulfill those desires that we have precisely as spiritual beings. It must however be pointed out that we are unable to exercise, develop or fulfill our spiritual capacities except through our relationship to the rest of the universe, both personal and impersonal, and in dependence on it.

This insight into our human nature does not depend on faith but on philosophical reflection on experience. But unless one recognizes this dimension to our human nature it is not possible to understand adequately the essentials of Christian faith.

2. In the light of the above philosophical anthropology a quite distinctive worldview emerges. The well-founded theories of contemporary science have enabled us to understand that the universe is an evolutionary process in which, over time, progressively more complex forms of being come into being through a real transformation of what preceded them. Humanity is the most complex (in its materiality) and the most simple (in its spirituality) being known to us. As such we contain in a transformed unity all the preceding forms of being discovered by the sciences. Though they are part of us we are not reduced to them but transcend them. In addition we are able to contain the universe as such in consciousness and endow it with meaning and value in our decisions and our acts. Thus the universe as a whole is most properly understood as a plurality of persons. It is the object of our thought and choice, and its impersonal aspects constitute the milieu in which a plurality of persons can exist and a medium in which interpersonal transactions can bring about our development and fulfillment. Put simply, there is more of reality in a person than a fundamental particle or physical force.

Again it must be stressed that such a worldview, with its metaphysical implications, is a purely philosophical one and owes nothing to Christian faith. But if one does not share it, understanding the essentials of Christian faith will be difficult. In fact it is 
probably the dominance of different conceptions of human nature and worldviews that make authentic faith difficult in our contemporary scientific and secular culture.

3. We experience our transcendent subjectivity in all our cognitive and volitional activity. And at the same time we experience our openness to and inclination towards something absolutely transcendent that is immanent in our activity. I say 'something' because it is not any specific object of knowledge or desire; nor is it simply we ourselves as the knowing, acting subjects. It is however inherent in our conscious free activity as the condition that makes it possible, not merely as a 'logical' condition but as a reality that is essentially mysterious.

There is an unlimitedness to human consciousness and desire that indicates an unlimited reality and value as its source, an absolutely transcendent reality and value that is nevertheless immanent in our experience of ourselves as knowing, choosing subjects.

A reflection on our capacity for free choice will make this clearer. When we deliberately affirm something as true or choose something as good our act transcends all the causal networks the universe contains and the sciences are able to discover. Not that the laws of nature break down in us, or the social influences that have formed us cease to operate. Indeed they are absolutely necessary if we are to act at all. But they are not sufficient. If they were we would not be free. And what holds for the free action must also hold for the capacity to act freely that is part of normal human nature as outlined above. It follows that causal networks of the universe (such as are necessary to produce human beings from pre-human nature), though necessary are themselves insufficient to produce beings like us with the capacity for free action. There must therefore be another kind of causality at work, within the evolutionary process though beyond the reach of science, that is absolutely transcendent of the universe though immanent in its processes to bring us into being.

4. The production of beings with the capacity for free acts such as ourselves is only the clearest case of a feature that is universal in the evolutionary process uncovered by modern science. This is a process in which really new forms of being are continually coming into existence through a transformation of what preceded them. The most dramatic examples, apart from the emergence of humanity, are those of consciousness from preconscious being, of living from non-living, and of the universe itself from an initial singularity. In general cosmic evolution is from the simple and dispersed to the complex and centred. And at every stage the new form of being is not simply the product of what previously existed. Though necessary, physical things and forces are insufficient to produce biological organisms. Something more is required, a causality that transcends the cosmic process our science can investigate though immanent in it. A number of examples from contemporary science lend support to this philosophical position.

5. Human beings, though transcending impersonal reality, are nevertheless dependent on it for all we are and do. There is no thought without images, no images without sensations, no sensations without sense organs sensitive to a spatio-temporal environment in which alone we can exist, express ourselves and communicate with others. This is what is known as our historicity. As transcendent beings we are able to develop an inner life, to live by meanings and values. But we can only do this in a process that unfolds in time and in a milieu that identifies us in space. We develop ourselves only in dependence on what is other than us. And, most importantly, through our relations with other persons, in a social and cultural milieu that humanity itself has constructed. Historicity is a 
feature of the life of individuals and of humanity as a whole.

6. For beings such as we are our relations with other persons are crucial for the exercise, development and fulfilment of our distinctively personal capacities of self-consciousness and self-determination. And a philosophical phenomenology of inter-subjectivity shows that certain definite kinds of relationship with others are necessary for this. It reveals that the more we are influenced by other persons in whom these capacities are already developed, the more self-determining we are enabled to be. Apart from such influence we are unable to grow as persons. This can appear to contradict the fact that the capacity in question is that for self-determination, for action that is free. But careful analysis of experience proves the contrary: The more I am influenced by the other in a certain way, the more the act is my own.

This is in fact what our philosophical anthropology should lead us to expect. For we saw there that the existence of beings with a capacity for self-determination was only possible as the effect of an absolutely transcendent cause immanent in the evolutionary process. And in our experience of ourselves as knowing, choosing subjects we are conscious of an apprehension of reality that is absolute and of a desire for something of absolute value. This experience is however not objective; the transcendent source of our knowing and valuing is only implicit in our experience of ourselves. Here however, in the relationships with others in which we exercise develop and fulfill our capacities for self-knowledge and self-affirmation, we actually experience in an objective way the power and presence of an absolutely transcendent personal reality immanent in the very relationships themselves. It is precisely this that explains the paradoxical 'interpersonal causality' whereby the more we are subject to the influence of the other, the more selfdetermining we become. If the influence exercised on us was simply that of a finite cause other than us, the more it caused us to act, the less the act would be our own. But the opposite is the case. We are thus bound to recognize that within the relationships in which my capacity for self-determination is developed there is a truly transcendent personal cause at work, whose influence is incommensurable with that of finite causes, personal or impersonal.

7. This notion of incommensurability is of the utmost importance for dealing in a theological way with Christian faith. It arises however through a philosophical phenomenology of intersubjectivity and is founded on our actual experience of personal growth in relationships with other persons. The fact that this is something universal to humanity and not exceptional should not blind us to its essentially mysterious character. If the analysis is true, then it is indeed the case that we have real experience of something absolutely transcendent, and therefore mysterious, in our ordinary interpersonal relations.

Rahner corroborates this insight and its importance in his treatment of the notion of creatureliness and our experience of this. Being a creature in this context entails a unique relationship to our transcendent creator, a relationship that is traditionally expressed by the notion of incommensurability. The notion of the incommensurability of creature and creator is central to classical theism and taken for granted by Aquinas. One cannot add God and the universe and make two. This is not because either is unreal, or that God and the universe are identical, but because there is no common measure in terms of which they could be added to or subtracted from one another. The reality of each is too different. An analogy would be that of a poet composing a poem about himself. One cannot say there are two poets, the one composing and the one in the poem. But to say there is only one is misleading because the poem already exists in the 
poet's mind. Rahner makes use of this idea in his discussion of our creatureliness. The following quotation serves the purpose of making the connection with the idea of 'interpersonal causality' outlined above.

The radical dependence and the genuine reality of the existent coming from God vary in direct and not in inverse proportion. In our human experience it is the case that the more something is dependent on us, the less it is different from us, and the less it possesses its own reality and autonomy. The radical dependence of the effect on the cause and the independence and autonomy of the effect vary in inverse proportion.

But when we reflect upon the real transcendental relationship between God and a creature, then it is clear that here genuine reality and radical dependence are simply just two sides of one and the same reality, and therefore they vary in direct and not inverse proportion. We and the existents of our world really and truly are and are different from God not in spite of, but because we are established in being by God and not by anyone else (1978:79).

The best example of this apparently contradictory, but in reality paradoxical, relation is that of the human capacity for self-determination. In our discussion of Rahner's philosophical anthropology it was pointed out that only an infinite cause could be sufficient to bring beings with the capacity for freedom into existence, albeit through the causal mechanisms of evolution. It follows that even the exercise, development and fulfillment of our capacity for self-determination is the effect of the creative causality of God. Human freedom means freedom from total determination by worldly causes not freedom from God. It is precisely this paradoxical truth that my analysis of interpersonal causality is intended to substantiate.

With this we come to the end of my account of the philosophical foundations of Rahner's theology. An important element in it is his notion of historicity. This, in Rahner's words, means that "man as subject and as person is a historical being in such a way that he is historical precisely as a transcendent subject; his subjective essence of unlimited transcendentality is mediated historically to him in his knowledge and his free self-realization" (1978:140). It follows from this that what we call history is not just a succession of events, as might be said of pre-human evolution. It is only history insofar as it is a process endowed by humans with human meaning and purpose. It is this that historians must engage with, not only the list of events. In fact even to list the events involves naming them and thus engaging with their meaning. To an account of human history we now turn.

8 The philosophical conception of human nature and analysis of experience given above is one that has, of course, been developed in history and in quite recent history at that. And as outlined above it contains, as an essential element in it, a conception of a transcendent creator of the universe immanent in all that happens but incommensurable with it. Such a conception approximates closely, though not completely as we shall see, to the one Jesus called Abba and which Christians recognize as their god. (I use the term 'God' as a proper name to designate precisely this same one.) So for Christian theologians human history is studied from the viewpoint of faith in Jesus with all that that entails. All human history is thus seen as 'salvation history', in the sense that we believe that God is still continuing his creative engagement with the world, though now principally through the exercise of human freedom. Put otherwise, evolution still continues. But now it is an evolution of human consciousness, culture and community. And it is not simply progressive, but proceeds by fits and starts, both development and decline. In its early stages humanity is largely undeveloped as far as its central capacities are 
concerned. Its knowledge of the universe is very limited. And in its life it has to struggle to personalize the instinct it has inherited from its prehistory. There is space for ill-will as well as error in the incompleteness of its development. Powerful emotions of fear and anger rather than insight and responsibility can direct the course of history. This is why creation in its human stage does not proceed at a constant or increasing rate. There is immaturity to educate and spiritual ill-health to heal. In the real universe, whose latest form is humanity, creation is salvation.

Early humanity reveals quite clear signs of religious experience and behaviour, attaching particularly to death but also manifesting in art and ritual. The notion of a god is that of a source of power transcending human power but capable of fulfilling deep desires that emerge in all cultures from our common human nature. Religion is the human attempt to access and enact such power in the service of this fulfillment. Because of the transcendent dimension of our human nature this fulfillment is always seen in absolute terms, as complete and enduring, whatever particular need happens to be the present focus of concern. But in the history of religion two needs, and hence two desires, emerge as fundamental: The desire to overcome all forms of disunity between people and the desire to overcome sickness and death. These two fundamental projects of human life can be seen as the expression of the duality of human nature already described, our relation-to-self and our relation-to-the-other, our spirituality in selfconsciousness and self-determination, and our bodiliness in dependence on other persons and our impersonal milieu for its enactment. And they are beautifully depicted in the story of Adam and Eve and the story of the Tower of Babel. For Rahner, and for me, the built-in goal of human history, is well expressed in the novel definition of the Church contained in the Dogmatic Constitution on the Church of the Second Vatican Council: "By her relationship with Christ, the Church is a kind of sacrament or sign of intimate union with God, and of the unity of all mankind. She is also an instrument for the achievement of such union and unity." (1966:15)

As humanity develops in the course of history so too does its conception of its gods. One must therefore speak of a history of revelation, where revelation refers to insight into the nature of our god and its relation to us. This history is part of the history of salvation and it too is an evolution, though not one of a steady increase in insight. In primal cultures the worldview is mythic, sacral. The gods are personified powers of nature. But always they are conceived of as transcendent in the sense of possessing powers that transcend the human but which we need to fulfill our deep desires. For that reason they are regarded with a special awe, as holy, wholly other. In different cultures they have different names and are described in different ways.

Though the gods of primal cultures are transcendent in the sense that they transcend human power they are not transcendent in the strict sense. The power they are believed to have may be sufficient to fulfill human nature as that is understood in that culture. But primal cultures do not have insight into human freedom and spirituality. And as such, human beings have deep desires that only a truly transcendent being, incommensurable with us, could fulfill: The desire for a true and hence universal community of persons and the desire for a death-transcending life.

Historians speak of an axial period of human history, and in particular in the history of religion. This is usually dated from about $1000 \mathrm{BCE}$ to 300BCE. During this period there occurred in several different traditions (Hindu, Buddhist and Jewish are usually mentioned, and sometimes also that of Greek philosophy) the beginning of the realization of the existence of a genuinely transcendent being. For our purposes the 
Jewish tradition provides the best introduction to Christian faith. In this tradition Moses is credited with this revelation. And this revelation is developed by the Jewish prophets. In Jewish history by the time of Jesus, the conception of our humanity and our god that has developed has become the foundation for a whole edifice of related ideas concerning the intentions of our god and the character of our relationships with our god and one another. In short there has developed a whole conception of the meaning of human life and history that is centred on the conception of our god. The Jewish people are to become the nucleus of a universal community of humanity that is united and ruled over by Yahweh, their god. Indeed Yahweh is understood as planning to be present himself in the midst of his people to inaugurate a kingdom in which he will rule forever. In this kingdom not only sin but also death itself will be overcome. The organizing principle and fundamental law of this kingdom will be the law of love. The process whereby the kingdom of Yahweh will be established, and sin and death overcome, will involve Yahweh somehow taking the effects of sin and death upon himself and in this way destroying their negative power over humanity.

In the Jewish scriptures these ideas are given graphic expression by the prophets. There are the Suffering Servant Songs of Deutero-Isaiah, the story of the Tower of Babel in Genesis, and the prophetic visions of the City of God and the Resurrection of the people of Israel. The whole of history is seen as moving towards a climax in which their god himself appears to inaugurate a never-ending rule. In this way the Jewish religious and cultural tradition gives powerful expression to the deep desire of our transcendent human nature for a community of complete reciprocity and mutuality that is not brought to an end by death. And it is in this form that it is understood by Jesus and his followers.

9. And this brings us to the theology of Rahner. This theology is of course based on Jesus and our experience of him. It might seem unnecessary to stress that Rahner understands that Jesus was, is and will always be a real human being. But two thousand years of theology have produced many other views, ranging from some or other kind of 'superman' (ubermensch) to a mere humanoid apparition of God. Strange though it may seem, Christianity has been dogged from it's beginning by monophysitism, the 'physis' in question being not human but divine. Some of the trouble no doubt can be put down to technical theological language being misunderstood by non-theologians: The word hypostasis for instance, or even 'person'. But most of it has, I think, a more sinister source: The universal tendency towards idolatry.

Rahner puts the matter with admirable clarity. For instance, to say 'Jesus is God' is dangerously misleading. "For when we say that Peter is a man, the statement expresses a real identification in the content of the subject and predicate nouns. But the meaning of 'is' in statements involving an interchange of predicates (communicatio idiomata) in Christology is not based on such a real identification. It is based rather on a unique, otherwise unknown and deeply mysterious unity between realities which are really different and which are at an infinite distance from each other. For in and according to the humanity which we see when we say 'Jesus', Jesus 'is' not God, and in and according to his divinity God 'is' not a man in the sense of a real identification. The Chalcedonian adiairetos (unseparated) which this 'is' intends to express (DenzingerSchonmetzer 302) expresses it in such a way that the ansynchtos (unmixed) of the same formula does not come to expression. Consequently, the statement is always in danger of being understood in a monophysitic sense" (1978:290).

For clarity's sake in what follows I will always use the name Jesus to refer to the 
human person who lived, died and now lives a death-transcending life with the one he called Father and whom I call God. The Incarnation of God in the universe and in human history is indeed mysterious, but the mystery is all on the side of God and not at all on the side of Jesus. We know what Jesus is. We know nothing of what God is except that God is mysterious. But the mystery that God is, is revealed for Christian faith in the (human!) person of Jesus.

For Christian faith God (as the one Jesus called Abba) has a quite distinctive character and relationship to us. In the first place it is God who is now recognized as the source of our existence and the one whom we experience in our experience of ourselves as knowing, choosing subjects involved with other persons in a milieu of culture and of nature. And it is God whom we experience especially in those relationships with others in which we exercise, develop and fulfill those capacities that make us subjects, and, in particular, our desire for the fullness of personal community and death-transcending life. For Rahner nobody is without this experience, and it is in this sense that he uses the term 'anonymous Christian'. Of course experience is not knowledge, and primal cultures had only inadequate ideas of God, as are expressed in their religion. But for Rahner the whole of human history can be seen as an evolution towards the true understanding of the power that moves history towards its goal through the insights and freedom of humanity. And this is because he believes that human history is the history of God's self-communication to humanity. The notion of God's self-communication to humanity is the fundamental conception in Rahner's theology. It is this idea that defines both salvation and revelation for him.

The salvation of humanity consists in the creation of "the unity of humanity in union with God", to paraphrase the expression used by the Second Vatican Council. For Rahner the way to this is God's self-communication to us throughout human history, but finally and fully in the life of Jesus. For a union between God and humanity to exist it must be achieved in our human world, the world God created for this purpose. It cannot take place anywhere else, for human beings cannot be real anywhere else. We are 'evolution become conscious of itself'. However transformed, it is this universe that is our eternal home. And it has been created by God with the purpose of making it a home in which God can be with us. We don't go to God; God comes to us. This is the importance of Rahner's idea of God's self-communication. And so the Incarnation (the complete and therefore unsurpassable form of God's self-communication) is seen as the purpose of creation, and salvation as the purpose of the Incarnation. One must of course add that the notion of salvation is only appropriate because of sin; it is God's continuing creation and self-communication in the process of overcoming sin and the effects of sin in us. Finally, salvation can only be achieved if God's self-communication is accepted. It is Christianity's faith that it is, and completely, by Jesus. The acceptance of God's self-communication, by Jesus or by us, is also always the result of God's freedomcreating power in human acts - 'grace' in Rahner's terminology.

Revelation, as Rahner understands it, is not primarily the revelation of truths but the revelation of God himself. It is an aspect of God's self-communication, that which imparts the personal knowledge of God. This knowledge is personal knowledge, the knowledge of acquaintance, not knowledge of truths about God, not something that can be written down. It is thus not to be identified with scripture, whether Jewish or Christian. It is that which is possessed by the persons - prophets, apostles, Jesus himself - who write or are written about in the scriptures. Rahner, as I have already indicated, sees the history of God's revelation of God as coinciding with the whole of human history. And, as with salvation, revelation proceeds by fits and starts, developing in 
different ways and to different degrees in every culture and religion. It reaches an unsurpassable completeness only in Jesus.

10. Because Christian faith in God is faith in the one revealed in the person and life of Jesus, it depends on a knowledge of that person and that life. This is as true for those who were intimate with him before his death as it is for us. But for us this knowledge is mediated to us by that original community as it has expanded through two thousand years. And it is complicated by the fact that the original community (and its extension through time and space) was formed by a faith in Jesus' resurrection. So there is no way of getting to know anything (or anything of importance) about Jesus apart from those who believed in his resurrection. Certainly all the writings of the New Testament are written from the point of view of this faith. Modern scientific study of these has helped a great deal to form an objective picture of what Jesus said and did and of the effect this had on his followers. But the project of building up a detailed biography of Jesus is doomed to failure. That does not matter however from the point of view of Christian theology. As theologians we want an accurate picture of the faith of Jesus' followers and, if possible, the faith of Jesus himself. Since the authors of the New Testament writings believed that their faith in God was the same as that of Jesus - since they had acquired it through their intimacy with him - they are providing us with first hand information about the nature of that faith. And that is what we really want. Rahner (though not himself a biblical scholar in the strict sense, had studied more works of biblical scholarship than most who are) certainly believed that we are in possession of sufficient knowledge of what the first followers of Jesus believed, and of what Jesus himself believed, to be able to share their faith. He is supported in this conviction both by his philosophical insights into the capacities and deep desires of our human nature, as well as by the history of religion I have sketched above. And he certainly believed that if a person was not in touch with his own humanity, but had a mind full of contemporary illusions or ancient myths, then authentic Christian faith would be virtually impossible.

Rahner felt that one can say something about Jesus' own self-understanding. Jesus certainly saw himself as standing in the historic line of Jewish prophets, but with this difference: He was bringing this line to an end. All other prophets saw themselves as bearers of God's word to Israel, but that word was not seen as God's final word. The prophets saw their words as God's words ("The Lord your God says this" and "Thus says the Lord"), but still expected God to say more. Jesus, on the other hand, had a message whose very content implied that it was the final one, final because complete and unsurpassable. Rahner sees Jesus' gospel of the kingdom of God as implying God's self-communication to the world, not just a message. And not even God could do more than that.

So the first stage of human history was coming to an end; the final stage was beginning. "Was beginning...?" Rahner believes that Jesus did not know, perhaps even was mistaken, about the 'times and seasons' of God's full and irrevocable entry into human history, his 'kingdom'. But he also believes that Jesus saw himself as in some way or other responsible for its inauguration. And that he felt this responsibility because of his experience of God's extraordinary closeness to him. Here is how he puts it: "Jesus experienced a relationship to God which he experienced as new and unique in comparison with other men, but which he nevertheless considered to be exemplary for other men in their relationship to God ... Jesus experienced in himself that radical and victorious offer of God to him which did not exist before in this way among 'sinners', and he knows that it is significant, valid and irrevocable for all men. According to his 
own self-understanding he is already before the resurrection the one sent, the one who inaugurates the kingdom of God through what he says and what he does in a way that did not exist before, but now does exist through him and in him. At least in this sense the pre-resurrection Jesus already knew himself to be the absolute and unsurpassable saviour." (1978:253-254)

Certainly his followers saw him in that light, and even before the resurrection experience. Unless they had his death would not have been the catastrophic disaster it clearly was for them. And nor would their experience of the resurrection have had the meaning that it did. Since Christian faith as a whole grows from that experience - in relation to the life and death that preceded it - we will have to deal with it in some detail.

11. It is taken for granted that specifically Christian faith in God begins with Jesus' followers' experience of his resurrection. Rahner recognizes that resurrection has nothing to do with resuscitation. Nor is he particularly concerned with the 'appearances' of the risen Jesus, or the empty tomb. As with the case of Jesus' virgin birth, we have no way of reaching anything genuinely historical. Nor does that matter. It is the meaning of whatever happened that is important, not the fact that something extraordinary occurred. And in the case of the resurrection no occurrence, however extraordinary, would be sufficient either to produce or to justify what the followers of Jesus came to believe. What then, according to Rahner, did they come to believe? That his death had been 'overcome', so that he was alive with a life that transcended death altogether. But the meaning of this 'new' life was that his claims regarding God's kingdom had been vindicated. Rahner puts it like this: "This Jesus with his concrete claim and his history is experienced in the resurrection experience as of permanent validity and as accepted by God. What real claim inseparable from himself...? The claim that there is present with him a new and unsurpassable closeness of God which on its part will prevail victoriously and is inseparable from him. He calls this closeness the coming and the arrival of God's kingdom..." (1978:279) He then adds "By the resurrection, then, Jesus is vindicated as the absolute saviour" (1978:279). As we have already seen, salvation (for Rahner) is God's self-communication to humanity in a history of sin and death in order to enable us to share the life of God. And he defines the notion of saviour as "that historical subjectivity in which, first, this process of God's absolute self-communication to the spiritual world as a whole exists irrevocably; secondly, that process in which this divine self-communication can be recognized unambiguously as irrevocable; and thirdly, that process in which God's self-communication reaches its climax insofar as this climax must be understood as a moment within the total history of the human race ..."(1978:194).

To put this (I hope) more simply: Faith in the resurrection of Jesus entails the belief that God is fully present in human history in Jesus in order to make us, like Jesus, sharers in a sin- and death-transcending life with God. So much as regards the content of faith in the resurrection; what of its grounds? Rahner rejects both 'mystical visions' and 'sense experience' as possible grounds on philosophical as well as theological grounds.

To understand fully what he identifies as the grounds of Christian faith one needs to explain in a little more detail what the attitude of faith consists in. It is an attitude of a person as a whole to the personal presence of God. I say 'as a whole' since the attitude of faith comprises cognitive, volitional and emotive elements. All our powers are involved. The cognitive element can best be understood as the kind of knowledge that 
one person can come to have of another. It is not theoretical or matter of fact. And this explains the centrality of the volitional element in faith; personal knowledge of a person can only be gained if the persons involved 'open up' to each other, if each wills to know and be known. And finally, such self-transcendence through intimate personal knowledge, and self-donation through receptive affirmation, of the other, answers our deep desire for personal communion and hence is supremely emotionally satisfying, and, when the other concerned is God, is all we could ever hope for. It is for this reason that, in the traditional terminology, Christian faith is held to consist in the three 'theological virtues' of faith (the cognitive), charity (the volitional) and hope (the emotive).

With this conception of faith in mind we can return to the situation of the first followers of Jesus. As a result of their experience of Jesus' resurrection the attitude I have just described was formed in them in relation to God whom they now recognized as personally present to them in the person of Jesus. The foundation of the attitude of faith had been laid by the metanoia, the change of heart, brought about in them through their relationship with Jesus before he died. They had been enabled to love him with the gift-love of charity with which he had loved them. They now saw that love of this kind had an absolutely transcendent source. Then came the death that destroyed all their hopes, though it could not destroy the love. It was this love then that gave them eyes to recognize that Jesus was alive through the same transcendent power that had changed their hearts. Now it was their minds that were changed; it was with these changed minds that they now fully understood what had happened to their hearts - and to Jesus.

For Rahner it is of the utmost importance, if one is to avoid a mythological understanding of the resurrection experience, to grasp the unity of the experience his followers had of Jesus before and in his death with their experience of his resurrection. Both are in the last resort an experience of God present in Jesus to answer our deep desire for the fullness of personal community in a death-transcending life. The experience of the resurrection is an experience of sharing it with Jesus, of Jesus sharing it with them. If one asks what actual form this experience took the only truly historical factor one can identify is their experience of one another. It was in their actual community with each other as the ones who had been changed by Jesus that they experienced his 'real presence', his continuing community with them in spite of the fact that he had died. The two disciples who 'spoke' with him on the road to Emmaus and 'broke bread' with him came to know that he was present with them. But an observer who had not known Jesus would have seen only two on the road to Emmaus or at the table in the inn.

The followers of Jesus believed that Jesus was alive because after his death they came to believe that they now shared a common life with him that had come to them from him, a life that transcended both sin and death. Authentic Christian faith is not possible without believing in the possibility of the fulfillment of one's desire for the fullness of personal community in a death-transcending life. Recognizing the achievement of the fulfillment of both these desires in the case of Jesus is the form taken by Christian faith in God. The writings of the New Testament document the discovery, first by Jesus and then, through their relationship with him, by his followers, of the existence of a community-creating, death-transcending power at work in their lives. And not only that. Their experience of Jesus eventually led his followers to the conviction that it was not only the power of God but God's personal presence in Jesus, and through him in them, that they had experienced. 
12. This experience, of both Jesus and his followers, of being in the personal presence of God, not in some symbolic 'religious' or mystical way, but in the ordinary sense of the presence of one human person to another, is of course the historical root of the Christian definition of God as the Trinity. And in essence it is very simple. According to the New Testament record that documents what his followers came to believe, Jesus experienced his intimacy with the one whom he called Abba as God's gift to him of all that God is. He had become the 'possessor' of God's (the Father's) own self-expression (Rahner's term for the New Testament 'Word'), his Word. And as a result he, a human person, had become a sharer in and agent of God's own love, his Holy Spirit. It was this recognition of God's presence in Jesus' death-transcending life, and in theirs, that is the heart of the resurrection experience of the first followers of Jesus.

As there is no space in this article to give a full account of Rahner's understanding of the doctrine of the Trinity I want to make one point in that regard that I have found very helpful. It is well-known that the terms translated 'person' in Trinitarian formulations do not mean what the word now means to us. There is no suggestion that God is a 'gang of three'! In God there is only one will, one intellect, one subjectivity. But it is less often realized that, as Rahner remarks in a footnote in his book on the Trinity, 'Hence within the Trinity there is no reciprocal 'Thou'. The Son is the Father's selfutterance which should not in its turn be conceived as 'uttering', and the Spirit is the 'gift' which does not give in its turn.' In all the New Testament texts where Jesus addresses the Father "a creaturely starting point for the 'Thou' addressed to the Father" is presupposed. (1970:76) This insight is extremely important if one is to avoid mythological interpretations of the Trinity, and also if one is to do justice to the foundations of the doctrine in the experience his followers had of Jesus.

13. I have noted that the idea of God's self-communication is the key concept in Rahner's theology. And of course it is one that fits the doctrine of the Incarnation very well. The Incarnation can be seen as the supreme expression of God's self-communication to the creation, to Jesus and so to the universe that has become conscious of itself in him and us. Rahner is fully aware of the problems inherent in the notion of God's self-communication to that which is not God, to a spatio-temporal reality in process of evolution and growth. First of all there is the problem of particularity. If it is really self-communication in the fullest possible way, successful self-communication that achieves its full acceptance, then it is something that must occur at a particular point in time and space. It is not just the offer and promise that occurs in every human life. This is the real uniqueness of Jesus. His life was the point at which God achieved what was only implicit in creation and only dreamed of by the prophets. That is the substance of Christian faith.

The way in which Rahner applies his conception of God's self-communication to achieve real insight into this most mysterious but fundamental conviction of Christianity is to my mind not only true to an authentic tradition but develops it as well. It involves three essential affirmations. The first is that God's indwelling in Jesus has the same kind of effect on him as it has on us. The uniqueness of the Incarnation and 'hypostatic union' does not lie there. The second affirmation is that faith in the Incarnation entails a quite distinctive conception of our creator. The third, which is closely bound up with the second, is that it is only strictly personal reality that provides the best analogy for understanding our relationship with God.

The first affirmation is a consequence of Rahner's determination to avoid mythical concepttions of the Incarnation. The human uniqueness of Jesus does not consist in a difference between him and us, but from his position in history, namely in being the 
event in which God's self-communication occurs. In Rahner's words, the "hypostatic union may not be seen so much as something which distinguishes Jesus from us, but as something which must occur once and only once when the world begins to enter upon its final phase". (1978:181) And this because "the intrinsic effect of the hypostatic union for the assumed humanity of the Logos consists precisely and in a real sense only in the very thing which is ascribed to all men as their goal and their fulfilment, namely, the immediate vision of God" (1978:200). Rahner is by no means denying an unusual or extraordinary human holiness to Jesus. He is simply getting rid of any suggestion of 'supernatural' characteristics resulting from God's incarnation in him.

The second affirmation, that the idea of God as creator must be transformed by the doctrine of the Incarnation, is a result of Rahne's view that the notion of creation must be seen as a secondary element within the more fundamental notion of Incarnation. Put differently, the Incarnation is the purpose of creation; creation is for the sake of Incarnation. Rahner's philosophical anthropology has prepared us for this idea. For our created nature comprises a dynamism towards an unlimited good that transcends our own powers to achieve. The Incarnation is God's fulfillment of this deep desire. As such it is "the unique and highest instance of the actualization of the essence of human reality" (1978:218). But if the doctrine of the Incarnation deepens our understanding of our human nature it does so even more in respect of our understanding of God.

We have already seen that the notions of immanence and transcendence apply equally to the idea of a creator. Although not the universe or a part of it, God is present in every part as its continuing creator. The Incarnation goes a step further: God becomes part of his creation, present in it and to it as one thing to another, as Jesus was present to his followers. The effect of this, on God as it were, is that the creation becomes his own in a new and deeper way. But how this is possible is another matter. How can the infinite creator, that is beyond time and space, become a spatio-temporal reality without ceasing to be the infinite creator. Here is Rahner's answer: "This brings us to an ontological ultimate which a merely rational ontology would perhaps never suspect. Such an ontology finds it difficult of course to take cognizance of this ultimate, and to insert it as a primal formula right into the primal beginnings and origin of its discourse. The absolute, or, more correctly, the absolute One in the pure freedom of his infinite unrelatedness, which he always preserves, possesses the possibility of himself becoming the other, the finite. He possesses the possibility of establishing the other as his own reality by dispossessing himself, by giving himself away" (1978:222). The idea is not new. It is already present in Augustine who taught that in the Incarnation God 'assumes by creating' and 'creates by assuming' a human nature. But what could lead us to suppose it true? Rahner offers some help: In the Incarnation God "creates by emptying himself, and therefore, of course, he himself is in the emptying. He creates the human reality by the very fact that he assumes it as his own. He, the Logos [which for Rahner is the Father's self-expression], constitutes the differentiation from himself by the fact that he retains it as his own, and, conversely: Because he truly wants to have the other as his own, he constitutes it in its genuine reality. God goes out of himself, he himself, he as the self-giving fullness. Because he can do this, because this is his free and primary possibility, for this reason he is defined in scripture as love" (1978:222). I think that this quotation gives us a clue to a sense in which this conception of God is not a contradictory one but embodies a deep and essential insight.

In discussing Rahner's philosophy of persons I made the point that it is only through our relationships with other persons that we are enabled to develop as persons. This seems uncontroversial yet it is highly mysterious. For human persons are self-deter- 
mining. And it is precisely for the development of this capacity that we are dependent on the influence of others in whom it has already been developed. There is not space in this paper to discuss this more fully but both I and Rahner believe we can show that it is only in certain kinds of relationships with others that this is true, namely those in which we are recognized and affirmed as persons and hence infinitely precious. The more I am subject to this kind of influence, the more (and not the less) self-determining I become. And the more I am enabled to surrender myself to this influence of the other, the more (and not the less) do I possess myself. It is only by virtue of a self-transcendence in knowing the other and a self-donation in loving them for their own sake, that I come to know and love myself truly. This is the paradox of what I call 'interpersonal causality'.

If all this is true then I think it provides an authentic analogy for what Rahner wants to affirm of God in the Incarnation. If we see all acts of God ad extra on the model of this interpersonal causality, then I think we see that the expressions used above need not be contradictory but answer to something that, though mysterious, is part of our own experience. Here is what Rahner says:

Because in the Incarnation the Logos creates the human reality by assuming it, and assumes it by emptying himself, for this reason there also applies here, and indeed in the most radical and specific and unique way, the axiom for understanding every relationship between God and creatures, namely that closeness and distance, or being at God's disposal and being autonomous, do not vary for creatures in inverse, but rather in direct proportion. Christ is therefore man in the most radical way, and his humanity is the most autonomous and the most free not in spite of, but because it has been assumed, because it has been created as God's self-expression (1978:226).

One ought to add to this that though a correct phenomenology of intersubjectivity does capture our experience of 'interpersonal causality', it does not explain it. In fact it could be shown that it is only because the transcendent causality of God is at work in the interpersonal transaction that it can achieve the effect of personal growth and community in us. ${ }^{1}$ This is of the utmost importance in our understanding of the metanoia produced by Jesus in his original followers, and indeed for the way we think of grace and the Church.

14. I will complete this summary exposition of how Rahner (and I under his influence) tells the Christian story with a brief sketch of his theology of the Church. I have already indicated the novel definition of the Church contained in the Dogmatic Constitution on the Church of the Second Vatican Council's Lumen Gentium. I have no explicit proof that Rahner was himself the originator of this definition, but it is highly likely, since he was by far the most respected and influential among the periti who served the bishops at the Council. But that does not really matter since it corresponds in every detail to Rahner's conception of the nature and purpose of the Church. And this has as its focus and foundation the idea of the Church itself as the sacrament of Jesus continuing 'real presence' in the world in order that God be personally present to humanity and humanity be enabled to respond to this presence.

The classical conception of sacrament that Rahner uses includes two elements, that of sign and that of cause: A sacrament is something that really causes what it symbolically signifies. In the case of the Church, in order to be the sign of Jesus', and hence God's incarnate, continuing presence in the world, it must be a historically specific and identifiable reality. Put simply, it must fulfill the function that Jesus' physical body had

I have tried to do this in the two articles in Modern Theology referred to in the bibliography. 
in identifying his personal presence to his followers in the days before he died. This it does by virtue of its existence as a specific institution since apostolic times. This is provided, for Rahner, by the worldwide episcopate in communion with the bishop of Rome. But his understanding of this needs to be spelt out lest it be misunderstood. In the first place a bishop is identified as the authoritative preacher of Jesus' 'gospel' and the president of the celebration of the rite that expresses Jesus' 'real presence' and 'holy communion' with his followers. So it is the person of the bishop that identifies a local manifestation of the Church. I use these terms carefully. The Church as a worldwide institution is not like a multinational corporation or political state with its principle of unity in its headquarters or head of government. The Church must be seen instead as a 'community of communities', in which each community is everything that all others are, including the community each has with all the others. To use a very humdrum image, The Church is not like a fish (whose principle of unity is its single nervous system centred on its brain), but like a jelly fish whose nature subsists in every part equally. In this understanding of the Church the proper function of the bishop of Rome is not like that of the head of a government or of an organization but the purely symbolic one of identifying the community of communities that constitutes the Church.

As far as the reality signified by the historically identifiable Church is concerned there are two aspects of Rahner's thought that ought to be understood. In the first place the function of the Church is identical with that of Jesus, namely the salvation of humanity. As we have seen, for Rahner this consists in the 'unity of humanity in union with God', to paraphrase the Council's definition. For this to happen God must be present in our world (and the Church is the sign of this presence) and we must recognise this presence and respond to it (and the Church's function in this respect is to be the instrument that brings about this recognition and response). It is with regard to the distinction of this twofold function of the Church that much misunderstanding can occur.

Rahner often uses the term 'universal salvific will' to identify God's intention to save humanity as a whole and every individual. In this he is simply echoing the affirmation of Lumen Gentium that "those also can attain to everlasting salvation ... who, without blame on their part, have not yet arrived at an explicit knowledge of God, but who strive to lead a good life, thanks to his grace" (1.14). This affirmation occurs at the end of a passage in which the possibility of salvation for (in this order) Roman Catholics in good standing (!), other Christians, Jews, Muslims and believers in other religious traditions is also affirmed. In other words anyone at all can be saved! In what sense then can it be true that, as traditionally expressed, extra ecclesiam nulla salus? Only if the distinction outlined above of the two functions of the Church is properly understood. It is the distinction in fact of two necessary conditions for salvation, an objective and a subjective. Objectively it is necessary for God to be present in the human world as in the person of Jesus. And the Church alone is the historical sign of this. No other religion could be this sign since no other religion or spiritual tradition believes this. On the other hand God is present in every person and in all personal relationships revealing his presence and inspiring our response to it. And this is true in every religion and spiritual tradition, and even in none, even in explicitly atheistic ideologies such as Marxism and secular humanism. A fortiori it ought also to be true of the members of the Church, surrounded as they are by the objective signs, in the teaching, the worship and the way of life, that manifests the incarnate presence of God. Alas it is not necessarily so, since an authentic recognition of and response to this presence depends on subjective factors, the real faith, hope and charity in one's character that has been acquired in one's life. 
It is because he is thinking of this subjective recognition and response that Rahner speaks of 'anonymous Christians'. It does not at all imply a lack of authenticity or holiness in non-Christians, or the automatic possession of authenticity or holiness in Roman Catholics for that matter. It simply would not make sense for, say, Jewish or Muslim believers, to speak of anonymous Jews or Muslims, since they do not believe in an objective (incarnate) presence of God in the world as Christians do.

With this rather sketchy account of Rahner's theology of the Church I conclude this already overlong paper. I have tried to give a summary and clear account of Rahner's telling of the Christian story and hope that the reader will have caught something of the flavour of his thought. That is really all I can hope for, since there is no shortcut to a deep understanding of Rahner. Years of study are needed. I have spent such years but still can't say whether or not I have achieved this. But I can say how much I value what he has given me.

15. The title of this collection, How are they telling the story? contains several ambiguities, as is pointed out in Ernst Conradie's editorial. It is my view, and I think Rahner's, that there is a Christian story. In every age and place the story told by the first followers of Jesus, the gospel or kerygma, has to be told again in words that ring true to teller and hearer alike. And in spite of all the many works he has written, the treatises on particular points relevant to the understanding and communication of Christian faith, Rahner too has his version of the story. Foundations of Christian Faith, his final attempt to articulate the essential elements in the 'idea of Christianity' end with an epilogue in which he offers us his attempt to construct a contemporary creed. He offers more than one formula, but here is one: "The incomprehensible term of human transcendence, which is present is man's existential and original being and not only in theoretical or merely conceptual reflection, is called God, and he communicates himself in forgiving love to man both existentially and historically as man's own fulfillment. The eschatological climax of God's historical self-communication, in which this selfcommunication becomes manifest as irreversible and victorious, is called Jesus Christ" (1978:454). Very Rahner! But a story nonetheless.

To tell the full Christian story is inevitably to tell the story of the universe, and within that, the story of human history including the story of Jesus. For Rahner, and I think rightly so, this is to tell the story of God. I have stressed in this paper how the notion of God's self-communication is the foundational conception in Rahner's theology, and how other Christian notions such as creation and salvation and revelation are dependent on it. Making this point Rahner writes: God's "capacity to be creator, that is, the capacity merely to establish the other without giving himself, is only a derived, delimited and secondary possibility which ultimately is grounded in this real and primordial possibility of God, namely, to be able to give himself to what is not God, and thereby really to have his own history in the other, but as his own history. In their innermost essential ground creatures must be understood as the possibility of being able to be assumed, of being the material for a possible history of God. God establishes creatures by his creative power insofar as he establishes them from out of nothing in their own non-divine reality as the grammar of God's possible self-expression." (1978:222).

The best way to express the essence of personal beings such as we are is to tell our story. If we are indeed God's image, then this must be true also of God. For Christian faith then, the story of humanity is the story of God. 


\section{BIBILOGRAPHY}

Rahner K

1965a. Hominisation: The Evolutionary Origin of Man as a Theological Problem. London: Burns and Oates.

1965b. The Theology of Death. London: Burns and Oates.

1966. The Church and Sacraments. London: Burns and Oates.

1967. The Christian of the Future. London: Burns and Oates.

1970. The Trinity. London: Burns and Oates.

1978. Foundations of Christian Faith. London: Darton, Longman and Todd.

1983. The Love of Jesus and the Love of Neighbour. London: St Paul Publications.

1985. The Practice of Faith. London: SCM Press.

Shutte A

1984. "What Makes Us Persons?" Modern Theology 1, 67-79.

1986. "How Jesus Saves Us". Journal of Theology for Southern Africa 55, 3-14.

1987a. "A New Argument for the Existence of God". Modern Theology 3, 157-177.

1987b. "Community, Apartheid and the Metaphysics of Humanity in Genesis 1-11". Philosophy and Theology 2:1, 57-75.

1993. The Mystery of Humanity. Cape Town: Snailpress. 